\title{
術後ドレッシング材の有用性に関する前向き研究
}

\author{
川上広 高* 山王朋 佳* 竹之内 剛* \\ 恒 吉 康 弘**砂 原 伸彦** 小宮 節 郎*
}

\section{Prospective Trial on Usefulness of Using Postoperative Dressings}

Hirotaka Kawakami*, Tomoka Sanno*, Tsuyoshi Takenouchi*, Yasuhiro Tsuneyoshi**, Nobuhiko Sunahara**, and Setsuro Komiya*

[はじめに］今回私達は，整形外科手術後の創治癒におけるドレッシング材の有用性と問題点を明らか にすることを目的とした前向き研究を行ったので報告する. [対象と方法] 2008 年 7 月以降, 当院にて手 術施行された人工関節置換術（THA, TKA） 33 例，春椎手術（胸腰椎椎弓形成術, 腰椎後方固定術） 27 例を対象とした。術後ドレッシング方法を 2 種類用意し，無作為に選択した。 [結果] 発赤を認めた割合

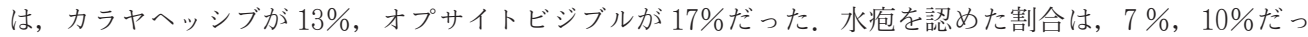
た。表皮離開を認めた割合は，7\%，13\%だった。ドレッシング材交換の頻度は，33\%，20\%だった。ド レッシング材交換の原因として, ともに浸出液多量, 水疮, 剥離の順となった。 [まとめ] ドレッシング 材の導入により, 創部観察が容易となり, 創管理が簡素化された。浸出液, 感染のリスク等を検討し, 適 切な術後ドレッシング材の使用が求められる.

Comparison examination was performed on usefulness and problems of dressing materials postoperatively.

Although wound observation is facilitated by the use of Karayahesive, the dressing material needs to be replaced. Frequent dressing material replacement prevents closing environment which promotes wound healing. Therefore, when Opsite Visible was introduced, wound care was simplified, but skin disturbance was observed. According to the trait of dressing material. It is important to choose the postoperative dressing material according to the characteristics of the dressing material.

In this examination, no significant difference was seen in the frequency of the adverse event.

Exudate, risk of infection, etc. must be reviewed and use of suitable postoperative dressing material is necessary.

Key words : dressing material (ドレッシング材), Karayahesive (カラヤヘッシブ), Opsite Visible (オプサイトビジブル), complication after operation（術後合併症）

\section{は じめに}

当院では， 2004 年以前は術後ドレッシング方法と してガーゼを使用していたが，発赤や水疮などの二次 的損傷が起こっていた. 2004 年よりドレッシング材 を導入し，八イドロコロイドであるカラヤヘッシブ (アルケア)，および固定のためのトップドレッシング 材として，ポリウレタンフィルムである IV 3000 ド レッシング（Smith \& Nephew）を使用した。 ガー ゼよりもドレッシング材の方が，二次的損傷の明らか
な減少を認めた。しかし，浸出液が多い場合に，カラ ヤヘッシブのゲル化が進み, 交換を要することがあっ た。そのため， 2008 年 7 月より吸収パッド付きポリ ウレタンフィルムであるオプサイトビジブル (Smith \& Nephew）を導入した.

近年, 整形外科領域では術後ドレッシング材の使用 が一般的になってきている。ドレッシング材を比較検 討した様々なランダム化比較試験が行われているが, いずれも同様の成績でありドレッシング方法として標 準化されるには至っていない ${ }^{3)}$. 今回私達は, 整形外

\footnotetext{
* 鹿児島大学大学院運動機能修復学講座整形外科学 Department of Orthopaedic Surgery, Graduate School of Medical and Dental Sciences, Kagoshima University, Kagoshima, Japan

** 鹿児島赤十字病院整形外科 Department of Orthopaedic Surgery, Kagoshima Red Cross Hospital, Kagoshima, Japan
} 
科手術後の創治癒に打けるドレッシング材の有用性と 問題点を明らかにすることを目的とし，術後ドレッシ ング材の有用性に関する前向き研究を行ったので報告 する.

\section{対象と方 法}

2008 年 7 月以降，当院にて手術施行された人工関 節置換術（THA，TKA）33 例, 春椎手術（胸腰椎椎 弓形成術，腰椎後方固定術）27 例を対象とした。術 後ドレッシング方法を 2 種類用意し，無作為に選択し た。

表 1 : 症例の内訳

\begin{tabular}{c|c|cc}
\hline \hline \multicolumn{3}{|c}{ 症例の内訳 } \\
\hline 被覆材 & カラヤヘッシブ & オプサイトビジブル \\
\hline 性別 & 男性 11 例 & 男性 10 例 \\
& 女性 19 例 & 女性 20 例 \\
\hline 年齢 & $29-83$ 歳 & 36-86 歳 \\
& 平均 63 歳 & 平均 69 歳 \\
\hline 期間 & 2008 年 7月-11月 & 2008 年 7月-11月 \\
\hline 春椎手術 & 15 例 & 12 例 \\
THA & 6 例 & 5 例 \\
TKA & 9 例 & 13 例 \\
計 & 30 例 & 30 例 \\
\hline
\end{tabular}

カラヤヘッシブおよび IV 3000 ドレッシング群は 30 例，オプサイトビジブル群は 30 例だった。各群の 平均年齢は 63 歳, 69 歳だった。（表 1 )

創部の縫合は，皮下縫合およびスキンステープルと した。手術室での滅菌状態で，ドレッシング材によっ て創部を被覆した。症例は，みな同じ整形外科病棟で 看護された。創部状態は月，水，金に主治医による創 部観察を行った．基本的にはドレッシング材は被覆継 続し，術後10日目，むしくは14 日目で全抜糸した。

創消毒にはポビドンョードを用いた。

手術日から抜糸日までの期間で，有害事象の頻度を 検討した。また期間中のドレッシング材交換の頻度， 原因を検討した。

結果

発赤を認めた割合は，カラヤヘッシブが $13 \%$ ，才 プサイトビジブルが $17 \%$ ったた（図 1 ）有意差は認 めなかった。

水疮を認めた割合は，カラヤヘッシブが $7 \%$ ，オプ サイトビジブルが $10 \%$ った。（図 2 ）有意差は認め なかった。

表皮離開を認めた割合は，カラヤヘッシブが $7 \%$, オプサイトビジブルが 13\%だった。（図 3 ）皮下組織 より深層に達しているような，再縫合が必要な症例は

\section{皮膚障害: 発赤}

Fisher's exact probability test

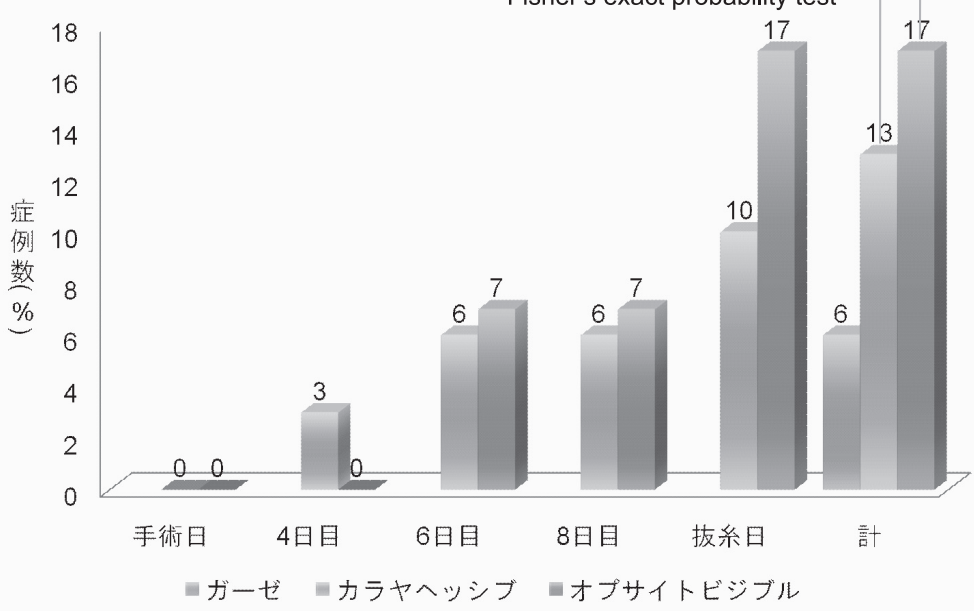

図 1 発赤を認めた割合は，カラヤヘッシブが $13 \%$ ，オプサ イトビジブルが 17\%であり，有意差は認めなかった． 


\section{皮膚障害: 水疮}

Fisher's exact probability test

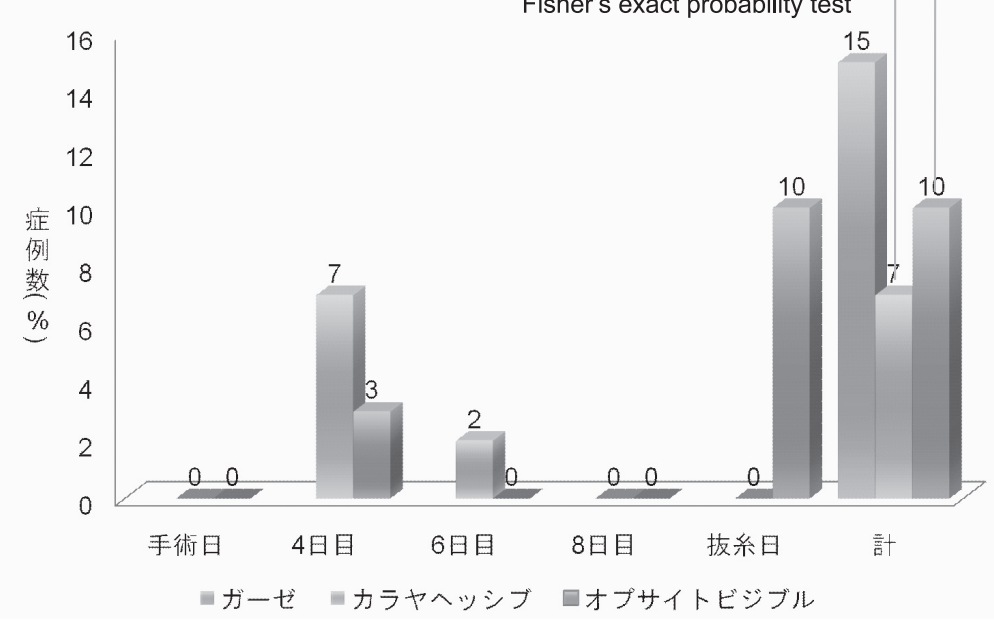

図 2 水疮を認めた割合は, カラヤヘッシブが 7\%, オプサイ トビジブルが $10 \%$ あり, 有意差は認めなかった.

\section{皮膚障害: 表皮離開}

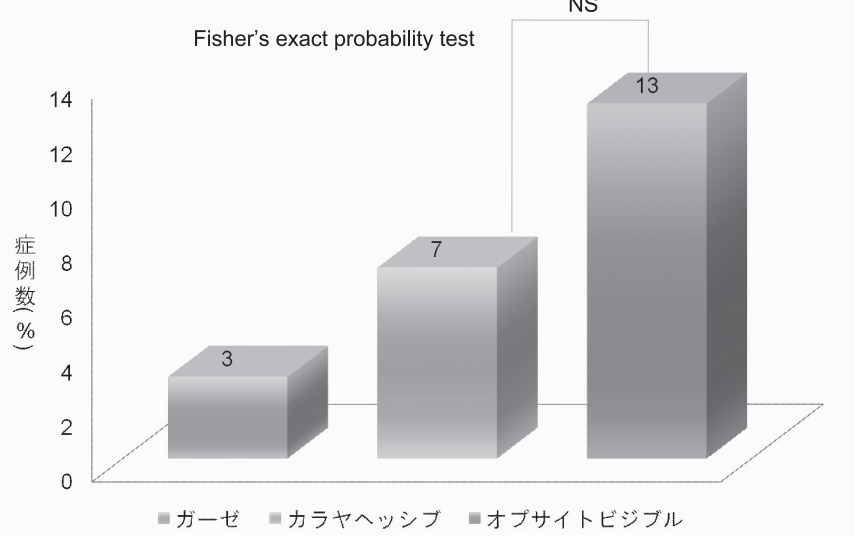

図 3 表皮離開を認めた割合は，カラヤヘッシブが $7 \%$ ，オプ サイトビジブルが 13\%であり，有意差は認めなかった。

認めなかった．有意差は認めなかったが，オプサイト ビジブルに表皮離開が多い傾向があった。

ドレッシング材交換の頻度は，力ラヤヘッシブが 33\%，オプサイトビジブルが 20\%だった.（図 4）力 ラヤヘッシブは，早期からドレッシング材の交換が必 要とされた。有意差は認めなかったが，カラヤヘッシ ブにドレッシング材交換が多い傾向があった。
ドレッシング材交換の原因として, カラヤヘッシブ, オプサイトビジブルともに浸出液多量, 水疱, 剥離の 順となった。（図５）特にカラヤヘッシブにおいては, 交換の理由の $72 \%$ が浸出液多量であり, 浸出液のコ ントロールが不十分と考えられた。 


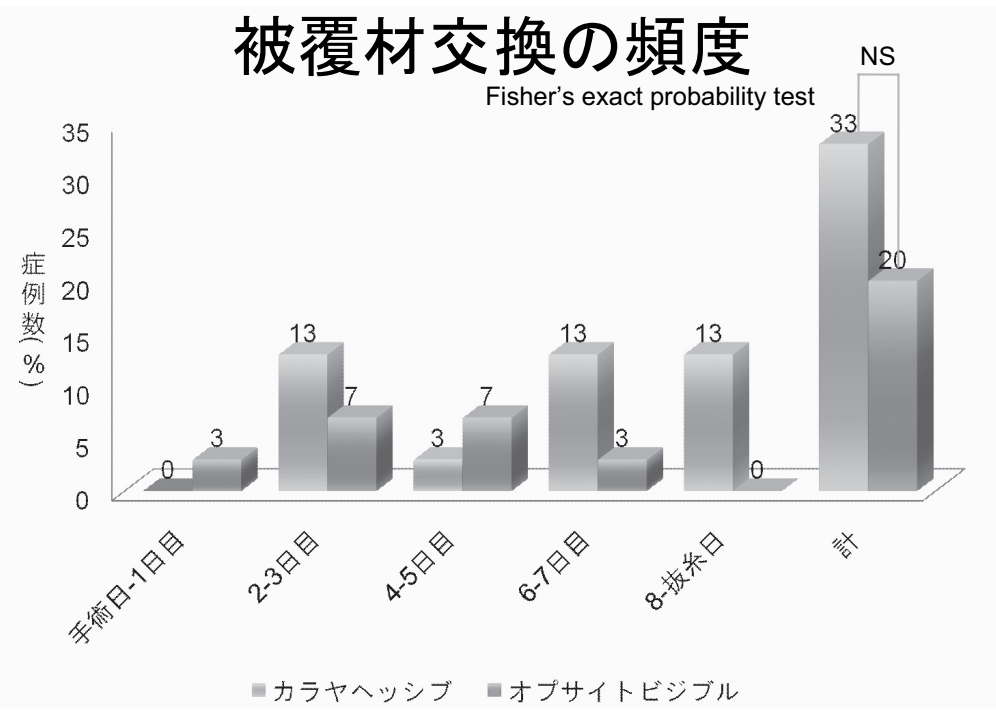

図 4 ドレッシング材交換の頻度は, カラヤヘッシブが $33 \%$, 才 プサイトビジブルが 20\%であり，有意差は認めなかった。

\section{被覆材交換の原因}

カラヤヘッシブ® + IV $3000^{\circledR}$

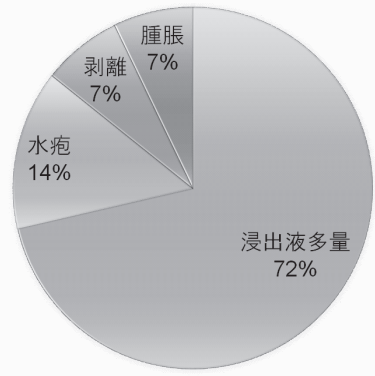

オプサイトビジブル®

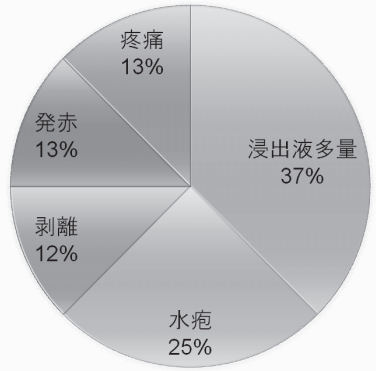

図 5 ドレッシング材交換の原因として，カラヤヘッシブ，オプサイ トビジブルともに浸出液多量, 水疮, 剥離の順となった。

考

察

創傷治癒においては，まず創の適度な湿潤環境を保 持しながら，肉芽形成の促進を考える。肉芽形成が進 めば，肉芽組織の収縮反応と新たな上皮形成によって 創の縮小を図る．利用可能なドレッシング材の豊富さ にも関わらず，創傷部位特異的なドレッシング材の指 針となるエビデンスは少ない ${ }^{8)}$. そのため，創傷治癒 に沶いて，適切なドレッシング材を選択することが，
必要となる。

創面の乾燥状態は避けなくてはならないが ${ }^{5)}$, 浸出 液が創に貯留し創周囲皮膚が浸軟する状態も感染が危 惧され，治癒環境としてはよくない ${ }^{6)}$. 湿潤環境を創 面に形成する機能は，ドレッシング材それぞれに特徵 がある。

カラヤヘッシブは，親水性および疎水性コロイドか ら形成されており，親水性コロイドには，創の浸出液 を吸収し，膨潤して適度な湿潤環境を保持する作用が 
ある。一方，疎水性コロイドには水や細菌の浸透を防 ぐ作用がある. 問題点として, カラヤへッシブは, 浸 出液のコントロールが不十分であり，創周囲皮膚が浸 軟しやすく, 浸出液により著しく混濁したり, 完全に ゲル化したりした場合, 感染の誘発や発見の遅れが危 惧される ${ }^{21}$.

IV 3000 ドレッシングは, 高透過性ポリウレタンフィ ルムから形成されており，トップドレッシング材とし て, 高い QOL，適度な湿潤環境を長期間維持し，創 面に固着せず，ドレッシング材の性能を十分に発揮さ せ，浸出液の多い創でも閉鎖療法の幅を広げるドレッ シング材といえる4).

オプサイトビジブルは, 吸収パッド抢よびポリウレ タンフィルムから形成されており, 吸収パッドには過 剩な浸出液を吸収保持する作用がある。一方，ポリウ レタンフィルムにはある程度の水蒸気を拡散しつつ外 部污染を防ぐ作用がある. 問題点として, オプサイト ビジブルは, 皮膚障害の頻度が多く, その原因として, ドレッシング材の弾性が低く, 創面に対しストレスが かかっていると考えられる．ドレッシング材の弾性不 足は水疮化の要因となる ${ }^{11}$.

カラヤヘッシブの使用によって, 創部観察が容易と なったが, ドレッシング材交換を必要とした。頻繁な ドレッシング材交換は, 創傷治癒を促進するために閉 鎖環境を保つことを妨害する ${ }^{7}$. そのため, オプサイ トビジブルを導入したところ，創管理が簡素化された が，皮膚障害が目立った。ドレッシング材の特徵に合 わせて, 術後のドレッシング材を選択することが重要 だと考えられた。

\section{ま と め}

術後創治癒におけるドレッシング材の有用性と問題 点に関して, 比較検討を行った。

ドレッシング材の導入により，創部観察が容易とな り，創管理が簡素化された。

今回の検討では, 有害事象の頻度に有意差は認めな かった。

浸出液, 感染のリスク等を検討し, 適切な術後ドレッ シング材の使用が求められる.

\section{参 考 文 献}

1) Cosker, T., et al. : Choice of dressing has a major impact on blistering and healing outcomes in orthopaedic patients. J. Wound Care, 14(1) : 27-29, 2005.

2）原田 仁ら：春椎脊䯣手術創管理におけるハイドロコ ロイド被覆材（カラヤヘッシブ）の有用性. 中部整災誌, 51(2) : 289-290, 2008.

3）堀野 敬ら：術後創感染症の管理に関するエビデンス。 臨外，62(2)：259-262，2007.

4）水口敬ら：各種フィルムドレッシング材の特徴に着 目したドレッシング法．形成外科，51(5)：561-568， 2008.

5）森友寿夫ら：整形外科医が知っておくべき創傷治療. 整形外科, 57(4)：451-457, 2006.

6) Ravenscroft, M. J., Harker, J., Buch, K. A. : A prospective, randomised, controlled trial comparing wound dressings used in hip and knee surgery : Aquacel and Tegaderm versus Cutiplast. Ann. R. Coll. Surg. Engl., 88 : 18-22, 2006.

7) Ubbink, D. T., et al. : Occlusive vs Gauze Dressings for Local Wound Care in Surgical Patients. Arch. Surg., 143(10) : 950-955, 2008.

8) Wynne, R., et al. : Effect of Three Wound Dressings on Infection, Healing Comfort, and Cost in Patients With Sternotomy Wounds. Chest, 125(1) : 43-49, 2004. 